\title{
COOPERATIVE AND NON-COOPERATIVE R\&D IN PRODUCT INNOVATION AND FIRM PERFORMANCE
}

\author{
Adam KARBOWSKI ${ }^{*}$ \\ Department of Business Economics, Collegium of World Economy, \\ SGH Warsaw School of Economics, Warsaw, Poland
}

Received 30 January 2019; accepted 15 July 2019

\begin{abstract}
The aim of this article is to investigate the impacts of cooperative and non-cooperative $\mathrm{R} \& \mathrm{D}$ strategies on product innovation and firm performance. Based on the industrial economics literature and the optimisation model, R\&D competition, R\&D cartelisation, and full industry cartelisation strategies of firms operating on a market with differentiated goods and simultaneous price and quality competition are considered. It is showed that R\&D cartelisation entails a loss of firm's product innovation compared with $R \& D$ competition. However, profit-maximising firms do not prefer the $R \& D$ competition strategy. They prefer to pursue either R\&D cartelisation or full industry cartelisation strategies, depending on the elasticity of demand with respect to the firm's investment in R\&D. The social cost of R\&D cartelisation is a loss of product innovation, and the social cost of full industry cartelisation is both the loss of product innovation and the loss of consumer surplus due to a relatively high price and low output of the final product. The latter results carry significant implications for the modern business and public policy.
\end{abstract}

Keywords: R\&D, strategy, innovation, firm performance, price competition, quality competition.

JEL Classification: L1, O3.

\section{Introduction}

Cooperation in innovation has been identified as a valuable $\mathrm{R} \& \mathrm{D}$ strategy to complement the internal R\&D efforts of firms (cf., e.g., Hofman, Faems, \& Schleimer, 2017; Belderbos, Gilsing, Lokshin, Carree, \& Sastre, 2018). Enterprises can cooperate with competitors in jointly exploiting existing products or technologies, to benefit from incremental innovations (Hofman et al., 2017). Firms can also cooperate with market rivals for more explorative purposes, to pursue radical innovations (Tushman \& Smith, 2002; Hofman et al., 2017). From the industrial economics viewpoint, interfirm cooperation in innovation is an effective mechanism to overcome the internal R\&D underinvestment problem (Czarnitzki, Ebersberger, \& Fier, 2007). In the presence of knowledge spillovers between competitors, the returns

*Corresponding author. E-mail: adam.karbowski@sgh.waw.pl 
from internal R\&D investments are not fully appropriable by the investing firms (Geroski, 1995; Czarnitzki et al., 2007; Belderbos et al., 2018). The newly obtained knowledge leaks out to competitors, affecting negatively private incentives to undertake $\mathrm{R} \& \mathrm{D}$, and leading to the underinvestment problem. Interfirm $R \& D$ cooperation allows to internalise knowledge spillovers, and enhance the appropriability of R\&D returns by cooperating firms (Czarnitzki et al., 2007).

Industrial economics models distinguish two distinct stages of an innovative behaviour of firms (d’Aspremont \& Jacquemin, 1988; Kamien, Muller, \& Zang, 1992; Lafay \& Maximin, 2017). In the first, investment stage, firms decide on their R\&D investment values. In the second, market behaviour stage, firms take decisions related to the final products (e.g., their price or output). A cooperative innovative behaviour can embrace two independent strategic dimensions, i.e., R\&D investment coordination, and knowledge sharing. R\&D investment coordination means that cooperating firms set their R\&D investment values in order to maximise the sum of economic profits of all cooperating firms. Knowledge sharing means, in turn, that cooperating firms do not keep their knowledge private, but they disclose their knowledge to all cooperating parties.

As Lin and colleagues (2006) notice, firms' decisions on R\&D investments and knowledge disclosure are integral part of the enterprise R\&D strategy (see also, Liu \& Atuahene-Gima, 2018). Observe that the enterprise R\&D strategy corresponds with the major questions that, according to Lin and colleagues (2006), should be answered by managers of innovation-oriented firms. These questions are: "Have we invested enough in R\&D?", and "Do investments in R\&D pay off in terms of firm performance?". These questions address the problem of optimal determination of corporate R\&D investments. Managers should set the R\&D investments in order to meet firms' performance objectives. Using the language of R\&D strategies distinguished by Kamien and colleagues (1992), managers should set the R\&D investments in order to maximise firms' individual economic profits (a non-cooperative case) or to maximise the sum of economic profits of all cooperating enterprises (a cooperative case).

The purpose of this paper is to investigate the impacts of firms' R\&D strategies on product innovation and firm performance. A majority of industrial economics papers addressing $\mathrm{R} \& \mathrm{D}$ strategies of firms focus on process innovations (see the literature review below). This paper instead concentrates on the relationship between $R \& D$ strategies and product innovations. In addition, this article sets out to analyse the effects of enterprise R\&D strategies on firm performance measured by the total economic profits and total revenues (sales).

This research focuses on oligopolistic industries with differentiated products and simultaneous price and quality competition (Chioveanu, 2012; Li \& Chen, 2018). Such industries constitute up to 50 per cent of all existing industries in a modern economy (for econometric estimations, see, e.g., Flath, 2012). Only the latter fact makes those industries important for public policy-makers, consumers, and managers. The real-life examples of those industries are: consumer goods (e.g., beverages, beer, cotton fabrics), fishing nets, medicines, paints, pianos, printing machines, tires and tubes for motor vehicles (Chioveanu, 2012; Flath, 2012).

Based on the optimisation model of firm's product innovation, it is showed that the R\&D cartelisation strategy entails a loss of firm's product innovation compared with the R\&D competition strategy. R\&D competition strategy turns out to be a not preferred strategy for firms. They 
prefer to pursue either R\&D cartelisation strategy or full industry cartelisation strategy, depending on the elasticity of demand with respect to the firm's investment in R\&D. The social cost of $\mathrm{R} \& \mathrm{D}$ cartelisation is a loss of product innovation, and the social cost of full industry cartelisation is both the loss of product innovation and the loss of consumer surplus due to a relatively high price and low output of the final product.

The present paper carries significant implications for business managers and policy-makers. Managers of firms operating in markets with differentiated goods and simultaneous price and quality competition may find a cooperative product R\&D strategy not appealing, when the major objective of the firm is to introduce product innovations. Policy-makers may, in turn, be more cautious about promoting product $\mathrm{R} \& \mathrm{D}$ cooperation between firms. The following analysis reveals that such cooperation may lead to a reduction of a product innovation and consumer surplus compared with the R\&D competition strategy.

This paper contributes to the theoretical industrial economics literature on R\&D strategies, innovation and firm performance. The majority of relevant theoretical industrial economics studies consider the relationship between a firm's R\&D strategy and process innovation. The present paper investigates the relationship between the enterprise $R \& D$ strategy and product innovation. At the same time, this paper investigates the relationship between the enterprise $\mathrm{R} \& \mathrm{D}$ strategy and firm performance. The theoretical analysis that allows to consider the impact of corporate R\&D strategy on both product innovation and firm performance makes this article unique among the relevant theoretical industrial economics papers.

Technically, the model present in this paper originally extends the concept of firm R\&D proposed by Lee and Sung (2005). The extensions involve: (i) the consideration of an impact of firm's R\&D strategy on product innovation and firm performance, (ii) the distinction between the autonomous and effective R\&D investments made by firms (this distinction allows to investigate the significance of knowledge spillovers between enterprises), and (iii) the possibility to compare prices of the final goods, firm's R\&D investments, revenues, and economic profits under different $R \& D$ strategies selected by firms.

The choice of a firm's R\&D strategy and its impact on innovation and firm performance is a current topic in a heated debate between scholars, managers and policy-makers (Belderbos et al., 2018; Zhou, Shan, \& Li, 2018; Bustinza, Gomes, Vendrell-Herrero, \& Baines, 2019). All parties of this debate underline the importance of a choice of a firm's R\&D strategy in building technological advantage, and, in particular, a choice of a degree to which a firm's knowledge is acquired externally (Zhou et al., 2018). The latter refers to the firm's ability to benefit from knowledge spillovers. The present paper constitutes a voice in a current debate on firms' R\&D strategies and their impact on innovation and firm performance in the presence of knowledge spillovers in the industry.

The paper is structured as follows. The next section provides an overview of the relevant innovation and economic literature. Further, a model of firm's product innovation is presented. Subsequent sections show and compare the impacts of enterprise R\&D strategies on product innovation, firm's revenues and economic profits. The paper is ended with a discussion of the main findings and conclusions. 


\section{Literature review}

Kamien, Muller, and Zang (1992) distinguish the following R\&D strategies of firms: (i) R\&D competition, (ii) R\&D cartelisation, (iii) research joint venture (RJV) competition, and (iv) RJV cartelisation (cf., Table 1).

Under R\&D competition, firms take R\&D decisions unilaterally, focusing on the maximisation of individual economic profits. Firms following an R\&D cartelisation strategy coordinate their R\&D investments, but they remain competitors on the final product market. Firms engaged in an RJV competition make their decisions on R\&D investments and final products unilaterally, yet they share the technological knowledge and, in particular, the results of R\&D works. An RJV cartelisation consists in a sharing of the results of R\&D works with a concurrent coordination of $R \& D$ investments (but the competition on the final product market is retained). If decisions on both $\mathrm{R} \& \mathrm{D}$ investments and final products are coordinated, firms follow a strategy of a full industry cartel (such a strategy has been distinguished by d'Aspremont \& Jacquemin, 1988).

Table 1. Types of enterprise R\&D strategies

\begin{tabular}{|l|l|l|}
\hline \multicolumn{1}{|c|}{$\begin{array}{c}\text { Enterprise R\&D } \\
\text { strategy }\end{array}$} & \multicolumn{1}{|c|}{ Investment stage } & \multicolumn{1}{|c|}{ Market behaviour stage } \\
\hline $\begin{array}{l}\text { R\&D competition } \\
\text { (R\&D rivalry) }\end{array}$ & $\begin{array}{l}\text { 1. No coordination of R\&D investment } \\
\text { decisions with competitors } \\
\text { 2. No technological knowledge sharing } \\
\text { with competitors }\end{array}$ & $\begin{array}{l}\text { No coordination of decisions } \\
\text { on product price or product } \\
\text { output with competitors }\end{array}$ \\
\hline $\begin{array}{l}\text { R\&D cartelisation } \\
\text { (R\&D cartel, R\&D } \\
\text { cooperation) }\end{array}$ & $\begin{array}{l}\text { 1. Coordination of R\&D investment } \\
\text { decisions with competitors } \\
\text { 2. No technological knowledge sharing } \\
\text { with competitors }\end{array}$ & $\begin{array}{l}\text { No coordination of decisions } \\
\text { on product price or product } \\
\text { output with competitors }\end{array}$ \\
\hline $\begin{array}{l}\text { RJV competition (RJV } \\
\text { rivalry) }\end{array}$ & $\begin{array}{l}\text { 1. No coordination of R\&D investment } \\
\text { decisions with competitors } \\
\text { 2. Technological knowledge sharing with } \\
\text { competitors }\end{array}$ & $\begin{array}{l}\text { No coordination of decisions } \\
\text { on product price or product } \\
\text { output with competitors }\end{array}$ \\
\hline $\begin{array}{l}\text { RJV cartelisation } \\
\text { (RJV cartel, RJV } \\
\text { cooperation) }\end{array}$ & $\begin{array}{l}\text { 1. Coordination of R\&D investment } \\
\text { decisions with competitors } \\
\text { 2. Technological knowledge sharing with } \\
\text { competitors }\end{array}$ & $\begin{array}{l}\text { No coordination of decisions } \\
\text { on product price or product } \\
\text { output with competitors }\end{array}$ \\
\hline $\begin{array}{l}\text { Full industry } \\
\text { cartelisation (full } \\
\text { industry cartel, full } \\
\text { industry cooperation }\end{array}$ & $\begin{array}{l}\text { 1. Coordination of R\&D investment } \\
\text { decisions with competitors } \\
\text { 2. No technological knowledge sharing } \\
\text { with competitors }\end{array}$ & $\begin{array}{l}\text { Coordination of decisions } \\
\text { on product price or product } \\
\text { output with competitors }\end{array}$ \\
\hline
\end{tabular}

Notes: own elaboration based on d'Aspremont and Jacquemin (1988), Kamien et al. (1992) and Lafay and Maximin (2017).

Research on firms' R\&D behaviour in strategic context was pioneered by Ruff (1969). The seminal works inspired by Ruff include papers by Spence (1984), Katz (1986), and d'Aspremont and Jacquemin (1988). The R\&D model developed by d'Aspremont and Jacquemin (1988) received utmost attention and was widely extended in subsequent years. These 
extensions involved, inter alia, an increased number of competing firms (cf., e.g., Kamien et al., 1992; Kamien \& Zang, 2000; Bourreau \& Dogan, 2010; Bourreau, Dogan, \& Manant, 2016), incorporation of the product differentiation (cf., e.g., Kamien et al., 1992; Bourreau \& Dogan, 2010; Bourreau et al., 2016), inclusion of price competition on the final product market (cf., e.g., Kamien et al., 1992; Ziss, 1994; Qiu, 1997; Hinloopen, 2000; Karbowski \& Prokop, 2018), inclusion of vertical cooperation of firms investing in R\&D (cf., e.g., Inkmann, 2000; Atallah, 2002), and internationalisation of firms' cooperation in R\&D (cf., e.g., Brod \& Shivakumar, 1997; Liu, Lu, \& Cheng, 2018).

D'Aspremont and Jacquemin (1988) showed analytically that firm's R\&D investments leading to process innovations are higher under full industry cartelisation strategy than under R\&D cartelisation strategy, and firm's $R \& D$ investments are higher under R\&D cartelisation strategy compared with R\&D competition strategy, if the level of knowledge spillovers in the industry is sufficiently large. Kamien and colleagues (1992), in a more general setup (KMZ model), but still in the context of process innovations, confirmed that firm's R\&D investments under $\mathrm{R} \& \mathrm{D}$ cartelisation are higher than under $\mathrm{R} \& \mathrm{D}$ competition, if the level of technological spillovers is large enough. The latter result has been also confirmed empirically, cf., e.g., Becker and Dietz (2004) or Aschhoff and Schmidt (2008). Further, Kamien and colleagues (1992) showed that firm's economic profits are higher under R\&D cartelisation strategy compared with R\&D competition strategy. Kamien and Zang (2000) showed in the extended KMZ model that the cooperative $\mathrm{R} \& \mathrm{D}$ investment and subsequent economic profit exceed the non-cooperative R\&D investment and economic profit, provided that the knowledge spillovers are sufficiently high. This again replicates the result that firm's process innovation is greater in the cooperative case than in the competitive one, if the technological spillovers are significant. In the presence of knowledge spillovers, the better appropriability of $R \& D$ returns under cooperative $R \& D$ investment compared with the non-cooperative one, enhances the firms' economic profits compared with the R\&D competition (Czarnitzki et al., 2007; Belderbos et al., 2018).

Certainly, cooperation or competition in $R \& D$ is not without an impact on the firms' behaviour on the final product market. D’Aspremont and Jacquemin (1988), Kamien and colleagues (1992) or De Bondt and Veugelers (1991) were among the first authors to note that cooperation of firms in $R \& D$ provides strong incentives to form a cartel on the final product market ( $\& \& D$ cooperation gives rise to a full industry cartelisation). This ultimately leads to a reduction of consumer surplus via higher prices of final goods or lower outputs (cf., Martin, 2006; Miyagiwa, 2009).

Please observe that papers cited above consider process innovations, i.e., innovations that lead to a reduction of manufacturing costs. There have been relatively few theoretical works to address the relationship between firms' R\&D strategies and product innovation. Motta (1992) showed that $\mathrm{R} \& \mathrm{D}$ cooperation of firms encouraged vertical product differentiation. Vertically differentiated products differ from each other in quality (Lee, 1999; Lee \& Sung, 2005). Product quality and price jointly determine consumer utility from a given product, and consumer utility impacts, in turn, the optimal firm's R\&D intensity (defined as the firm's R\&D investments divided by the total revenues; Lee, 1999; Lee \& Sung, 2005). R\&D intensity serves as a measure of enterprise innovation (for an elaboration, cf., section 2). Kaiser and 
Licht (1998) constructed a game where firms, first, decide on the R\&D strategy (R\&D cooperation or $\mathrm{R} \& \mathrm{D}$ competition), second, on the levels of $\mathrm{R} \& \mathrm{D}$ investments, and, finally, on the production outputs on the final good market. Interestingly enough, in addition to process innovations, Kaiser and Licht (1998) took into consideration product innovations. The authors showed that the firm's optimal investment in R\&D has virtually the same structure for both product and process innovations. Recently, Capuano and Grassi (2019) analysed the impact of technological spillovers on private R\&D investment and incentives to cooperate in product innovation. These authors showed that firms cooperate in $R \& D$ when the technological spillovers are sufficiently high and the costs of R\&D are sufficiently low.

A number of empirical studies have investigated the impact of enterprise R\&D strategy on product innovation, cf., e.g., Klomp and van Leeuwen (2001), Lööf and Heshmati (2002), Belderbos, Carree, and Lokshin (2006), van Beers and Zand (2014). These studies have concentrated on $R \& D$ cooperation and found a positive relationship between $R \& D$ cooperative strategy of firms and product innovation. Belderbos, Carree, and Lokshin (2004) analysed, in turn, the impact of $R \& D$ cooperation on firm performance considering innovative sales (sales of new to the market products) as a performance measure. These authors concluded that R\&D cooperation with competitors generates a rise in innovative sales per employee. More recently, Aguiar and Gagnepain (2017) analysed the impact of cooperative R\&D strategy of firms on profit margins. The effect of R\&D cooperation on profit margins turned out to be very limited.

It is worth observing that positive impacts of $\mathrm{R} \& \mathrm{D}$ cooperation on product innovation or firm performance are conditional upon the implementation of a successful interfirm governance mode (cf., Arslan-Ayaydin, Barnum, Karan, \& Ozdemir, 2014; Hofman et al., 2017; Belderbos et al., 2018). Such a governance mode has to effectively mitigate the opportunistic behaviour of cooperating partners and reduce the coordination gaps (Hofman et al., 2017). Possible contractual and financial instruments which assure an effective interfirm governance in R\&D are discussed, e.g., by Arslan-Ayaydin and colleagues (2014) or Hofman and colleagues (2017). Also, the effectiveness of various contractual and financial instruments mentioned above depends on the kind of a partner cooperating in R\&D (Belderbos et al., 2018).

Based on the above literature review, the following research hypotheses can be formulated. First, (i) since the firm's optimal investment in R\&D has virtually the same structure for process and product innovations (Kaiser \& Licht, 1998), (ii) for process innovations, the cooperative R\&D investments exceed the non-cooperative ones (cf., e.g., d’Aspremont \& Jacquemin, 1988; Kamien et al., 1992; Kamien \& Zang, 2000; Karbowski \& Prokop, 2018), and (iii) empirical studies report a positive relationship between $\mathrm{R} \& \mathrm{D}$ cooperation and product innovation (cf., e.g., Belderbos et al., 2006), it is hypothesised that firm's product innovation benefits from $\mathrm{R} \& \mathrm{D}$ cooperation compared with $\mathrm{R} \& \mathrm{D}$ competition. However, this hypothesis is formulated with some reservations, since the papers quoted in the premises (i)-(iii) do not consider quality competition between rival firms, which is an important building block of the proposed model (see the next section). Those papers focus on quantity or price competition, but still the market environment considered in those papers (an innovative oligopolistic industry with spillovers) is reasonably close to the business environment analysed herein. Second, (i) since cooperation of firms in $R \& D$ provides incentives to form a cartel on the 
final product market (cf., e.g., De Bondt \& Veugelers, 1991), and (ii) such a cartel rises prices of final goods compared with the market competition (cf., e.g., Martin, 2006; Miyagiwa, 2009), it is hypothesised that full industry cartelisation strategy brings higher prices of the final goods compared with strategies that do not cartelise the final product market. Third, since both R\&D cartelisation and full industry cartelisation strategies allow to internalise knowledge spillovers and enhance the appropriability of R\&D returns by enterprises (cf., e.g., Czarnitzki et al., 2007; Belderbos et al., 2018), it is hypothesised that economic profits are higher under cartelisation strategies than under a competitive (no coordination of R\&D investment decisions) strategy.

In the following sections, the above hypotheses are confronted with the theoretical propositions. A model of firm's product innovation (present in the next section) allows to derive those propositions. The building blocks of the model are the variables identified in the relevant literature (see, Table 2).

Table 2. The variables derived from the relevant studies

\begin{tabular}{|c|c|}
\hline Variable & Source of specification \\
\hline R\&D investment & $\begin{array}{l}\text { Spence (1984), Katz (1986), D’Aspremont and Jacquemin (1988), } \\
\text { Kamien et al. (1992), Kamien and Zang (2000), Czarnitzki et al. } \\
\text { (2007), Bourreau and Dogan (2010), Bourreau et al. (2016), Lafay } \\
\text { and Maximin (2017), Capuano and Grassi (2019) }\end{array}$ \\
\hline Marginal manufacturing costs & $\begin{array}{l}\text { D’Aspremont and Jacquemin (1988), Kamien et al. (1992), } \\
\text { Kamien and Zang (2000), Lee and Sung (2005), Lafay and } \\
\text { Maximin (2017) }\end{array}$ \\
\hline Price of a final good & $\begin{array}{l}\text { Kamien et al. (1992), Ziss (1994), Qiu (1997), Hinloopen (2000), } \\
\text { Karbowski and Prokop (2018) }\end{array}$ \\
\hline Output of a final good & $\begin{array}{l}\text { D’Aspremont and Jacquemin (1988), Kamien et al. (1992), } \\
\text { Kamien and Zang (2000), Lafay and Maximin (2017), Karbowski } \\
\text { and Prokop (2018) }\end{array}$ \\
\hline Quality of a final good & Lee (1999), Lee and Sung (2005) \\
\hline $\begin{array}{l}\text { Consumer utility from a final } \\
\text { good }\end{array}$ & Lee (1999), Lee and Sung (2005) \\
\hline Total revenues (sales) & $\begin{array}{l}\text { D’Aspremont and Jacquemin (1988), Kamien et al. (1992), } \\
\text { Kamien and Zang (2000), Lee and Sung (2005), Lafay and } \\
\text { Maximin (2017) }\end{array}$ \\
\hline Total profits & $\begin{array}{l}\text { D’Aspremont and Jacquemin (1988), Kamien et al. (1992), } \\
\text { Kamien and Zang (2000), Lee and Sung (2005), Lafay and } \\
\text { Maximin (2017), Karbowski and Prokop (2018) }\end{array}$ \\
\hline R\&D intensity & Lee (1999), Lee and Sung (2005) \\
\hline
\end{tabular}

Notes: own elaboration based on the literature review.

\section{The model of firm's product innovation in oligopoly with price and quality competition}

In this section, a model of firm's product innovation in an oligopolistic market with concurrent price and quality competition is developed. The following model sets out to investigate 
the firm's R\&D investment and product market behaviour, as in d'Aspremont and Jacquemin (1988), with the exception that, instead of process innovations, product innovations are considered. Based on the specification proposed by Lee and Sung (2005), the impact of firm's $\mathrm{R} \& \mathrm{D}$ strategy on product innovation and firm performance in a market with both price and quality competition can be assessed.

Following d'Aspremont and Jacquemin (1988), an oligopolistic final product market where two firms are operating, i.e., firm $i$ and firm $j$, is analysed. Since, in the following model, process innovations (they lead to a decrease in the marginal manufacturing costs) are not considered, the marginal manufacturing costs $(c)$ are constant. The product offered on the market is differentiated. This is a realistic assumption, since the majority of oligopolistic markets trade in differentiated products (cf., e.g., Goldberg, 1995; Mazzeo, 2002; Flath, 2012). Following the empirically verified model of an innovative behaviour developed by Lee and Sung (2005), consumer utility from the product offered by firm $i$ is a function of the product price and product quality, i.e., $U_{i}=U\left(p_{i}, a_{i}\right)$, where $p_{i}$ denotes price of the product, and $a_{i}$ stands for the product quality. The consumer utility is a decreasing function of the product price and an increasing function of the product quality, which constitutes a reasonable, realistic and empirically verified assumption (cf., e.g., Blattberg \& Wisniewski, 1989; Lee, 1999; Lee \& Sung, 2005; Dwicahyani, Rosyidi, \& Pujiyanto, 2019).

Let us further assume that the quality of the product depends on the effective R\&D investments devoted to product development (Lee, 1999; Lee \& Sung, 2005), i.e., $a_{k}=a\left(X_{k}\right)$, where $k=i, j$, and $X_{k}$ denotes effective product $\mathrm{R} \& \mathrm{D}$ investments of a firm. As Scherer (1984), Lee (1999) or Lee and Sung (2005) observe, product quality is produced primarily through R\&D efforts devoted to product development. Corporate R\&D efforts are measured by the R\&D investments made by firms (cf., e.g., Kamien et al., 1992; Belderbos et al., 2004; Belderbos et al., 2018). However, in the presence of knowledge spillovers in the industry, the effective (total) firm's R\&D investments that determine product quality exceed the autonomous (individual) R\&D investments (Kamien et al., 1992). As a result, product quality in a market with spillovers depends not only on producer's individual product R\&D efforts, but also on the product R\&D efforts put by producer's rivals. Function $a_{k}=a\left(X_{k}\right)$ has the following mathematical properties: $\frac{d a_{k}}{d X_{k}}>0$ and $\frac{d^{2} a_{k}}{d X_{k}^{2}}<0$, i.e., this is an increasing function with diminishing marginal returns on effective $\mathrm{R} \& \mathrm{D}$ investments. The assumption that the marginal returns on R\&D are decreasing has its empirical base, e.g., in Scherer (1980), Griliches (1998) or Kim (2018). According to Kamien and colleagues (1992), $X_{i}=x_{i}+\beta x_{j}$, where $x_{j}$ denotes the autonomous R\&D investments of firm $j, x_{i}$ stands for the autonomous R\&D investments of firm $i$, and parameter $\beta(0 \leq \beta \leq 1)$ models the knowledge spillovers (cf., e.g., Geroski, 1995; Kamien \& Zang, 2000; Kaiser, 2002). Knowledge spillovers can be understood as the benefits derived by a given firm from R\&D investment made by another firm. For higher values of parameter $\beta$, the given firm to a greater extent can improve the quality of its product due to R\&D investments made by the firm's rival.

Further, let us define demand for the product offered by a given firm. Following Lee and Sung (2005), demand for the product offered by a duopolist $i$ is as follows: $q_{i}=q\left(U_{i}, U_{j}\right)$, where $q_{i}$ denotes the demand for the product offered by firm $i$. This demand is an increas- 
ing function of the consumer utility from the product offered by firm $i$ and a declining function of the consumer utility derived from the product offered by the competitor. Such a specification is empirically valid, since consumers derive their demand for a particular good from its utility (cf., e.g., Lee, 1999; Lee \& Sung, 2005; Ding, Ross, \& Rao, 2010; Gostkowski, 2018), and can easily swap the product offered by a given firm for the product offered by the competitor if the latter product brings sufficiently large utility (cf., e.g., Lee \& Murphy, 2008; Wan, Huang, Zhao, Deng, \& Fransoo, 2018). Since utility of the product is contingent on price and quality, and the demand for the product depends on utility, the considered firms compete both in price and quality.

$S_{i}=p_{i} q_{i}$ denotes the total revenues (total sales) generated by firm $i$. The value of total sales measures the firm's size. As Park (2011) notices, most of the studies on corporate innovation and firm size take total revenues as a measure of firm size (cf., e.g., Acs and Audretsch, 1987; Cohen, Levin, \& Mowery, 1987; Lee \& Sung, 2005). This approach is followed not for opportunistic reasons, but for the purpose of logical consistency of the analysis. In the present demand-pull model of innovation, decisions on quality and price jointly determine the consumer utilities and the demand for an innovative product. In the model, quality and price decisions explicitly determine the total firms' revenues, but not the total assets or total employment (the rival measures of firm size used in the literature). It seems then natural to use a firm size measure explained within a model, i.e., the total revenues. Further, $\alpha_{i}=\frac{x_{i}}{S_{i}}$ stands for the R\&D intensity for firm $i$, i.e., the value of autonomous $R \& D$ investment related to the firm's size. The R\&D intensity is one of the input-based indicators of enterprise innovation (cf., e.g., Kleinknecht, van Montfort, \& Brouwer, 2002; Lee \& Sung, 2005; Karbowski, 2016; Medda, 2018). Enterprise innovation can be broadly understood as the firm's ability to create inventions and introduce them into marketplace (Burns \& Stalker, 1961; Dosi, 1988; Hurley \& Hult, 1998; Hult, Hurley, \& Knight, 2004). The innovation literature (cf., e.g., Milbergs \& Vonortas, 2006; Vonortas, 2018) distinguishes the following indicators of enterprise innovation: (i) absolute or relative value of firm's R\&D investments (input-based approach), and (ii) innovation counts, or number of patents obtained by a firm (output-based approach).

Let us now determine the product price, firm's size, R\&D investments and R\&D intensity, firm's economic profits under the generic strategic regimes: R\&D competition, R\&D cartelisation, and full industry cartelisation (cf., d'Aspremont \& Jacquemin, 1988; Kamien et al., 1992), in the context of product innovation. The obtained results are then compared and the implications for business and public policy are drawn.

\section{R\&D competition}

Under R\&D competition firms compete both on the final product market and at the R\&D stage. Firms set product prices and their R\&D investment levels to maximise individual economic profits. Let us now express the economic profit for firm $i$ :

$$
\pi_{i}=p_{i} q_{i}-c_{i} q_{i}-x_{i}
$$

where $c_{i}$ denotes the marginal manufacturing cost for firm $i$. From the condition of profit maximisation with respect to product price, it is derived that: 


$$
q_{i}+\left(p_{i}-c_{i}\right) \frac{\partial q_{i}}{\partial p_{i}}=0
$$

Knowing that $\varepsilon_{p}=-\frac{p_{i}}{q_{i}} \frac{\partial q_{i}}{\partial p_{i}}$ is a price elasticity of demand for the product offered by firm $i$, expression (2) can be rewritten as follows: $q_{i}+\left(p_{i}-c_{i}\right) \frac{-\varepsilon_{p} q_{i}}{p_{i}}=0$, and, further, following a few algebraic transformations, the following is obtained:

$$
p_{i}=\frac{\varepsilon_{p} q_{i} c_{i}}{-q_{i}+\varepsilon_{p} q_{i}}
$$

Note also that after few algebraic transformations, formula (2) can be rewritten as follows:

$$
S_{i}=\left(p_{i}-c_{i}\right) \varepsilon_{p} q_{i}
$$

Next, from the condition of profit maximisation with respect to the firm's autonomous $\mathrm{R} \& \mathrm{D}$ investment, the following is obtained:

$$
-1+\left(p_{i}-c_{i}\right) \frac{\partial q_{i}}{\partial x_{i}}=0
$$

Let us further observe that after few algebraic transformation of formula (5), the following is true:

$$
x_{i}=\left(p_{i}-c_{i}\right) \varepsilon_{x} q_{i}
$$

where $\varepsilon_{x}=\frac{x_{i}}{q_{i}} \frac{\partial q_{i}}{\partial x_{i}}$ denotes the elasticity of demand with respect to firm's autonomous R\&D investment. Based on formulas (4) and (6), the following is obtained:

$$
\alpha_{i}=\frac{x_{i}}{S_{i}}=\frac{\varepsilon_{x}}{\varepsilon_{p}}
$$

which defines the optimal R\&D intensity of the firm under R\&D competition.

Lastly, let us also express the optimal economic profit of firm $i$ under R\&D competition:

$$
\pi_{i}=q_{i} c_{i}\left(\frac{\varepsilon_{p}}{\varepsilon_{p}-1}-1-\frac{\varepsilon_{p} \varepsilon_{x}}{\varepsilon_{p}-1}+\varepsilon_{x}\right)
$$

\section{4. $R \& D$ cartelisation}

Under $R \& D$ cartelisation, firms set their $R \& D$ investment levels to maximise the sum of economic profits of all R\&D cartel members (firms coordinating their R\&D investments for a joint benefit). Let us write down the equation for the aggregate economic profit of the R\&D cartel:

$$
\pi^{\text {all }}=p_{i} q_{i}-c_{i} q_{i}-x_{i}+p_{j} q_{j}-c_{j} q_{j}-x_{j}
$$

From the condition of profit maximisation with respect to autonomous R\&D investment, it is obtained that:

$$
-1+\left(p_{i}-c_{i}\right) \frac{\partial q_{i}}{\partial x_{i}}+\left(p_{j}-c_{j}\right) \frac{\partial q_{j}}{\partial x_{i}}=0
$$


Note that $\frac{\partial q_{i}}{\partial x_{i}}=\varepsilon_{x} \frac{q_{i}}{x_{i}}$. Having taken account of the last expression and based on formula (10), it can be obtained that:

$$
-1+\left(p_{i}-c_{i}\right) \varepsilon_{x} \frac{q_{i}}{x_{i}}+\left(p_{j}-c_{j}\right) \frac{\partial q_{j}}{\partial x_{i}}=0 .
$$

Let $\varepsilon_{x j i}=-\frac{x_{i}}{q_{j}} \frac{\partial q_{j}}{\partial x_{i}}$ denote the elasticity of demand for the product offered by firm $j$ with respect to autonomous $\mathrm{R} \& \mathrm{D}$ investment of firm $i$. After simple algebraic transformations of expression (11), it is true that:

$$
x_{i}=\left(p_{i}-c_{i}\right) \varepsilon_{x} q_{i}-\left(p_{j}-c_{j}\right) \varepsilon_{x j i} q_{j} .
$$

The last expression shows the optimal R\&D investment of a firm that behaves as a member of an R\&D cartel. The R\&D cartelisation strategy provides for a coordination of $R \& D$ investments to maximise the aggregate economic profit (9), whereas on the final product market members of the R\&D cartel remain competitors, and strive for maximisation of their individual economic profits. Therefore, on the final product market, the firm aims at maximisation of its individual economic profit, and the profit-maximising price of the product manufactured by this firm can be found according to the following formula: $q_{i}+\left(p_{i}-c_{i}\right) \frac{\partial q_{i}}{\partial p_{i}}=0 \Rightarrow p_{i}=\frac{\varepsilon_{p} q_{i} c_{i}}{-q_{i}+\varepsilon_{p} q_{i}}$. The value of total sales generated by the firm, behaving as a member of the R\&D cartel, is expressed by the following equation: $S_{i}=\left(p_{i}-c_{i}\right) \varepsilon_{p} q_{i}$.

The optimal R\&D intensity of the firm under R\&D cartelisation strategy is, in turn, given by the equation below:

$$
\alpha_{i}=\frac{\left(p_{i}-c_{i}\right) \varepsilon_{x} q_{i}-\left(p_{j}-c_{j}\right) \varepsilon_{x j i} q_{j}}{\left(p_{i}-c_{i}\right) \varepsilon_{p} q_{i}}
$$

Let us also find the economic profit of firm $i$ which behaves as a member of an $R \& D$ cartel:

$$
\pi_{i}=q_{i} c_{i}\left(\frac{\varepsilon_{p}}{\varepsilon_{p}-1}-1-\frac{\varepsilon_{p} \varepsilon_{x}}{\varepsilon_{p}-1}+\varepsilon_{x}\right)+\left(p_{j}-c_{j}\right) \varepsilon_{x j i} q_{j}
$$

\section{Full industry cartelisation}

Under strategy of full industry cartelisation, firms set their R\&D investments and product prices to maximise the aggregate economic profit of the cartel.

From the condition of profit optimisation, it is true that:

$$
q_{i}+\left(p_{i}-c_{i}\right) \frac{\partial q_{i}}{\partial p_{i}}+\left(p_{j}-c_{j}\right) \frac{\partial q_{j}}{\partial p_{i}}=0
$$

Knowing that $\varepsilon_{j i}=\frac{p_{i}}{q_{j}} \frac{\partial q_{j}}{\partial p_{i}}$ denotes the elasticity of demand for the firm's product with respect to the price of the product manufactured by the firm's rival, equation (15) can be expressed in the following form: 


$$
q_{i}+\left(p_{i}-c_{i}\right) \frac{-\varepsilon_{p} q_{i}}{p_{i}}+\left(p_{j}-c_{j}\right) \frac{\varepsilon_{j i} q_{j}}{p_{i}}=0 .
$$

Based on (16), the price of the product offered by firm $i$ behaving as a member of full industry cartel can be found:

$$
p_{i}=\frac{\varepsilon_{p} q_{i} c_{i}+\varepsilon_{j i} p_{j} q_{j}-\varepsilon_{j i} q_{j} c_{j}}{-q_{i}+\varepsilon_{p} q_{i}}
$$

Further, based on equation (16), one can find the value of total sales generated by firm $i$ :

$$
S_{i}=\left(p_{i}-c_{i}\right) \varepsilon_{p} q_{i}-\left(p_{j}-c_{j}\right) \varepsilon_{j i} q_{j} .
$$

The R\&D investment of firm $i$ in a situation where it pursues the full industry cartelisation strategy is given by the following equation: $x_{i}=\left(p_{i}-c_{i}\right) \varepsilon_{x} q_{i}-\left(p_{j}-c_{j}\right) \varepsilon_{x j i} q_{j}$.

Based on the previous equation and on (18), the optimal R\&D intensity of firm $i$ that behaves as a member of full industry cartel can be found:

$$
\alpha_{i}=\frac{\left(p_{i}-c_{i}\right) \varepsilon_{x} q_{i}-\left(p_{j}-c_{j}\right) \varepsilon_{x j i} q_{j}}{\left(p_{i}-c_{i}\right) \varepsilon_{p} q_{i}-\left(p_{j}-c_{j}\right) \varepsilon_{j i} q_{j}} .
$$

Let us also compute the economic profit of firm $i$ which pursues a full industry cartelisation strategy:

$$
\pi_{i}=q_{i} c_{i}\left(\frac{\varepsilon_{p}}{\varepsilon_{p}-1}-1-\frac{\varepsilon_{p} \varepsilon_{x}}{\varepsilon_{p}-1}+\varepsilon_{x}\right)+\left(p_{j}-c_{j}\right) \varepsilon_{x j i} q_{j}+\frac{\varepsilon_{j i} q_{j}\left(p_{j}-c_{j}\right)}{\varepsilon_{p}-1}-\frac{\varepsilon_{j i} q_{j}\left(p_{j}-c_{j}\right)}{\varepsilon_{p}-1} \varepsilon_{x} .
$$

\section{6. $R \& D$ competition, $R \& D$ cartelisation and full industry cartelisation: a comparative analysis}

For comparison purposes, the relevant economic measures describing a firm operating under $\mathrm{R} \& \mathrm{D}$ competition, $\mathrm{R} \& \mathrm{D}$ cartelisation and full industry cartelisation are indexed as follows: rdcom for the R\&D competition, $r d c a r$ for the R\&D cartelisation, and fcar for the full industry cartel.

Let us start with a comparison of the prices of the final product offered by a firm. Based on (3) and (17), the following is true:

Proposition 1 (proofs of all propositions follow from direct computations and direct comparisons). $p_{i}^{\text {fcar }} \geq p_{i}^{r d c a r}=p_{i}^{r d c o m}$. The price of the final product manufactured by firm $i$ pursuing a full industry cartelisation strategy is higher or equal to the price of the final product manufactured by the same firm when it pursues the strategy of an R\&D cartel or R\&D competition.

Please observe that $p_{i}^{f c a r}=p_{i}^{r d c a r}=p_{i}^{r d c o m}$ for $q_{j}=0$ or for $p_{j}=c_{j}$, i.e., for the lack of production in firm $j$ or for the final product price equal to the marginal costs of manufacturing. The former case seems of little practical interest (is unrealistic), whereas the latter 
one appears, in turn, untypical of oligopolistic markets with a differentiated product (cf., e.g., Goldberg, 1995; Mazzeo, 2002). A standard situation for the markets of that type seems to be $p_{j}>c_{j}$, hence it can be expected that in real markets: $p_{i}^{\text {fcar }}>p_{i}^{r d c a r}=p_{i}^{r d c o m}$.

Let us now compare the values of total revenues (sales) generated by a firm in the three considered scenarios. Based on (4) and (18), the following holds:

Proposition 2. $S_{i}^{f c a r} \leq S_{i}^{r d c a r}=S_{i}^{r d c o m}$. The value of total revenues (sales) generated by firm $i$ pursuing the strategy of full industry cartelisation is lower or equal to the value of the revenues generated by the same firm when it follows the strategy of an R\&D cartel or $\mathrm{R} \& \mathrm{D}$ competition.

Let us note that $S_{i}^{f c a r}=S_{i}^{r d c a r}=S_{i}^{r d c o m}$ for $q_{j}=0$ or for $p_{j}=c_{j}$, i.e., for the lack of production in a rival firm or for the final product price equal to the marginal costs of manufacturing. Again, the former case seems of little practical interest, and the latter one appears untypical of oligopolistic markets with a differentiated product. A standard situation would be $p_{j}>c_{j}$, hence it can be expected that in real markets: $S_{i}^{f c a r}<S_{i}^{r d c a r}=S_{i}^{r d c o m}$.

Further, let us compare the R\&D investments of a firm in the three scenarios under analysis. Based on (6) and (12), the following is true:

Proposition 3. $x_{i}^{f c a r}=x_{i}^{r d c a r} \leq x_{i}^{r d c o m}$. The R\&D investment of firm $i$ competing in the area of $R \& D$ is higher or equal to the $R \& D$ investment of the same firm when it pursues the strategy of an R\&D cartel or full industry cartelisation.

Let us note that $x_{i}^{f c a r}=x_{i}^{r d c a r}=x_{i}^{r d c o m}$ for $q_{j}=0$ or for $p_{j}=c_{j}$, i.e., again for the lack of production in firm $j$ or for the final product price equal to the marginal costs of manufacturing. A standard situation for the considered markets seems to be $p_{j}>c_{j}$, hence it can be expected that: $x_{i}^{\text {fcar }}=x_{i}^{r d c a r}<x_{i}^{r d c o m}$.

Now, let us proceed to compare the R\&D intensities of the firm in the three scenarios under analysis. Based on (7), (13) and (19), the following holds:

Proposition 4a. $\alpha_{i}^{f c a r} \geq \alpha_{i}^{r d c a r}$. The R\&D intensity of firm $i$ when it pursues the strategy of full industry cartelisation is larger or equal to the R\&D intensity of the same firm when it follows the strategy of an R\&D cartel.

Proposition 4b. $\alpha_{i}^{r d c a r} \leq \alpha_{i}^{r d c o m}$. The R\&D intensity of firm $i$ when it pursues the strategy of an R\&D cartel is lower or equal to the R\&D intensity of the same firm when it follows the strategy of R\&D competition.

Proposition 4c. $\alpha_{i}^{r d c o m} \geq \alpha_{i}^{f c a r}$ for $\frac{\varepsilon_{x}}{\varepsilon_{p}} \leq \frac{\varepsilon_{x j i}}{\varepsilon_{j i}}$. For $\frac{\varepsilon_{x}}{\varepsilon_{p}} \leq \frac{\varepsilon_{x j i}}{\varepsilon_{j i}}$, the R\&D intensity of firm $i$ when it pursues the strategy of $R \& D$ competition is larger or equal to the $R \& D$ intensity of the same firm when it follows the strategy of full industry cartelisation.

Let us finally proceed to a comparison of the economic profits of firm $i$ in the three scenarios under consideration. Based on (8), (14) and (20), the following is true: 
Proposition 5a. $\pi_{i}^{r d c a r} \geq \pi_{i}^{r d c o m}$. The economic profit of firm $i$ when it pursues the strategy of an R\&D cartel is larger or equal to the economic profit of the same firm when it follows the strategy of R\&D competition.

Proposition 5b. $\pi_{i}^{r d c o m}<\pi_{i}^{f c a r}$ for $\varepsilon_{x}<\frac{\varepsilon_{x j i}\left(\varepsilon_{p}-1\right)}{\varepsilon_{j i}}+1$. For $\varepsilon_{x}<\frac{\varepsilon_{x j i}\left(\varepsilon_{p}-1\right)}{\varepsilon_{j i}}+1$, the economic profit of firm $i$ when it pursues the strategy of full industry cartelisation is larger than the economic profit of the same firm when it follows the strategy of R\&D competition.

Proposition 5c. $\pi_{i}^{f c a r}>\pi_{i}^{r d c a r}$ for $\varepsilon_{x}<1$. For $\varepsilon_{x}<1$, the economic profit of firm $i$ when it pursues the strategy of full industry cartelisation is larger than the economic profit of the same firm when it follows the strategy of an R\&D cartel.

Let us note that for $q_{j} \neq 0$ and $p_{j} \neq c_{j}$, Proposition $5 \mathrm{a}$ can be rendered in the form of a sharp inequality, i.e., $\pi_{i}^{r d c a r}>\pi_{i}^{r d c o m}$. As regards oligopolistic markets with a differentiated product, the latter form of Proposition 5a seems to be empirically sound (cf., Goldberg, 1995; Mazzeo, 2002).

The objective of firms is to maximise their economic profits. Knowing that, let us see which R\&D strategies would be chosen by firms operating in the considered industry. In table below, the economic profits of both firms are given.

Table 3. Profit-based decision table for R\&D strategies

\begin{tabular}{|c|c|c|c|}
\hline & $r d c o m$ & $r d c a r$ & $f c a r$ \\
\hline$r d c o m$ & $\pi_{i}^{r d c o m} ; \pi_{j}^{r d c o m}$ & $\pi_{i}^{r d c o m} ; \pi_{j}^{r d c a r}$ & $\pi_{i}^{r d c o m} ; \pi_{j}^{f c a r}$ \\
\hline$r d c a r$ & $\pi_{i}^{r d c a r} ; \pi_{j}^{r d c o m}$ & $\pi_{i}^{r d c a r} ; \pi_{j}^{r d c a r}$ & $\pi_{i}^{r d c a r} ; \pi_{j}^{f c a r}$ \\
\hline$f c a r$ & $\pi_{i}^{f c a r} ; \pi_{j}^{r d c o m}$ & $\pi_{i}^{f c a r} ; \pi_{j}^{r d c a r}$ & $\pi_{i}^{f c a r} ; \pi_{j}^{f c a r}$ \\
\hline
\end{tabular}

Notes: own elaboration.

Note that for $q_{j} \neq 0, p_{j} \neq c_{j}, q_{i} \neq 0$ and $p_{i} \neq c_{i}$, the R\&D competition strategy brings lower profits than the R\&D cartelisation strategy. Thus, profit-maximising firms should not select the R\&D competition strategies. As a result, the decision table can be simplified and expressed as follows:

Table 4. Simplified profit-based decision table for R\&D strategies

\begin{tabular}{|c|c|c|}
\hline & rdcar & $f c a r$ \\
\hline$r d c a r$ & $\pi_{i}^{\text {rdcar }} ; \pi_{j}^{r d c a r}$ & $\pi_{i}^{r d c a r} ; \pi_{j}^{f c a r}$ \\
\hline$f c a r$ & $\pi_{i}^{f c a r} ; \pi_{j}^{r d c a r}$ & $\pi_{i}^{f c a r} ; \pi_{j}^{f c a r}$ \\
\hline
\end{tabular}

Notes: own elaboration. 
Now let us consider two cases, i.e., (1) $\varepsilon_{x}<1$, and (2) $\varepsilon_{x}>1$. For the first case, full industry cartelisation strategy brings higher economic profit for each of the firms, so the pair ( fcar; fcar) should be finally selected. The latter leads to the following profits $\left(\pi_{i}^{f c a r} ; \pi_{j}^{f c a r}\right)$. For the second case, i.e., $\varepsilon_{x}>1$, R\&D cartelisation strategy brings higher economic profit for each of the firms, so the pair (rdcar; rdcar) should be finally selected, which leads to the following profits $\left(\pi_{i}^{r d c a r} ; \pi_{j}^{r d c a r}\right)$.

Based on the above analysis, it can be observed that in the considered industry, a cartel is likely to be formed, either at the R\&D stage only (the R\&D cartel) or as a full industry cartel involving also the production stage. Observe further that such a cartel would be internally stable (cf., d’Aspremont, Jacquemin, Gabszewicz, \& Weymark, 1983; Donsimoni, Economides, \& Polemarchakis, 1986; Prokop, 1999), since neither of the duopolists has an incentive to change its R\&D strategy or leave the cartel (cf., Tables 3 and 4).

\section{Discussion}

The findings present in the previous section suggest that the ultimate scenario (the formation of an $\mathrm{R} \& \mathrm{D}$ cartel or full industry cartel) that would unfold in the industry depends on the elasticity of demand with respect to the firm's investment in R\&D. If such an elasticity is relatively high, i.e., an increase in the firm's $\mathrm{R} \& \mathrm{D}$ investment by $1 \%$ results in a rise of demand for the final product by more than $1 \%$, such market is likely to form an R\&D cartel and the firms involved in it would be less innovative than under R\&D competition. The latter result does not support the first research hypothesis which predicted that firm's product innovation benefits from $R \& D$ cooperation compared with $R \& D$ competition. In fact, the above optimisation model generates the opposite finding, i.e., based on the proposed model, it is showed that firm's product innovation in an oligopoly with price and quality competition benefits from $\mathrm{R} \& \mathrm{D}$ competition compared with $\mathrm{R} \& \mathrm{D}$ cooperation. The probable explanation of this fact is that firms' rivalry in R\&D speeds up the technological race between oligopolists for enhance product quality. Higher quality of products is valued by consumers, and as a result, consumers' demand for higher quality products pulls in individual corporate product innovations. Quality competition, so important for product innovations (Anderton, 1999; Lee \& Sung, 2005), is then a crucial factor which qualitatively distinguishes oligopoly competition with process innovations (cf., d'Aspremont \& Jacquemin, 1988; Kamien et al., 1992; Kamien \& Zang, 2000; Karbowski \& Prokop, 2018) from oligopoly competition with product innovations (considered herein). A relatively high elasticity of demand with respect to the firm's R\&D investment translates into a high sensitivity of consumers to product quality enhancements, and promotes a fierce quality competition, but not price competition. As a result, the price of a final good under R\&D cartel does not differ from the price of a good when $\mathrm{R} \& \mathrm{D}$ competition takes place. A similar conclusion can be drawn with respect to the value of total revenues, i.e., under R\&D cartel it does not vary from the revenue generated in the $\mathrm{R} \& \mathrm{D}$ competition. Thus, the only social cost of the R\&D cartel is only a loss of product innovation compared with R\&D competition (cf., propositions 3 and $4 b$ ).

If the elasticity of demand with respect to the $\mathrm{R} \& \mathrm{D}$ investment is not sufficiently high (an increase in the firm's R\&D investment by $1 \%$ does not result in a rise of demand for the final 
product by more than $1 \%$ ), such a market is likely to develop a full industry cartel. When the demand with respect to the firm's R\&D investment is relatively inelastic, consumers do not attach an excessive value to product quality enhancements, and the quality competition in the industry should not be intense. The R\&D intensity of a firm involved in a full industry cartel will probably be higher than in an $\mathrm{R} \& \mathrm{D}$ cartel (cf., proposition $4 \mathrm{a}$ ), yet the value of $\mathrm{R} \& \mathrm{D}$ investment in absolute terms should not differ in those two scenarios (cf., proposition 3 ). The price of the final good under a full industry cartel will probably be higher than under an $\mathrm{R} \& \mathrm{D}$ cartel or $\mathrm{R} \& \mathrm{D}$ competition (cf., proposition 1). Interestingly, total revenue for the full industry cartel is likely to be lower than under R\&D competition or an R\&D cartel - cf., proposition 2 (which means that the output produced under a full industry cartel has to be relatively low, since the product price is relatively high). The finding in proposition 2 explains the differences in $\mathrm{R} \& \mathrm{D}$ intensities between full industry cartelisation and $\mathrm{R} \& \mathrm{D}$ cartelisation indicated above. The social cost of the full industry cartel would be then both the loss of product innovation (cf., propositions 3 and $4 \mathrm{c}$ ), and a loss of consumer surplus (due to a relatively high price, cf., proposition 1 , and low output of the final product). Observe that the finding in proposition 1 supports the second research hypothesis.

The formulas derived in the previous sections bring a practical value to business managers and policy-makers. For managers, a choice of a firm strategy in innovation activities is of great importance, especially in the context of today's turbulent and hypercompetitive environment where numerous technological changes take place (Turulja \& Bajgoric, 2019). Such an environment demands that firms are able to swiftly cope with the changing market conditions and make accurate strategic R\&D decisions. Turbulent business environment can play a role in boosting firms' product innovation (Turulja \& Bajgoric, 2019), especially in industries with both price and quality competition. Managers of high-tech firms operating in such industries have to screen out inferior $R \& D$ strategies. The present analysis shows that a cooperative product $\mathrm{R} \& \mathrm{D}$ strategy does not necessarily benefit firm's product innovation in oligopolistic markets with both price and quality competition. It is however showed that a cooperative product R\&D strategy can promote firm's profits compared with R\&D competition. The latter finding supports the third research hypothesis. Business managers have to choose which effect - profit enhancement (related to product R\&D cooperation) or product innovation enhancement (related to R\&D competition) - is more important from the current corporate strategic viewpoint.

The formulas developed in the previous sections can be also useful to policy-makers. Interestingly enough, the cooperation of firms in the form of an $\mathrm{R} \& \mathrm{D}$ cartel is perceived as a policy tool which promotes innovation (Belleflamme \& Peitz, 2010; Becker, 2015). Such an understanding of $\mathrm{R} \& \mathrm{D}$ cooperation may be surprising to some people, since numerous adverse social and economic effects produced by cartels are commonly known (cf., e.g., Connor \& Lande, 2005; Whelan, 2013). Anti-cartel policy measures became more stringent (both in the United States and in Europe) in 1990s. Enforcement of the competition laws was then substantially enhanced and, most importantly, leniency programs were introduced to effectively use the prisoner's dilemma to break cartels. But, the cartel prohibition law applies only to specific forms of cooperation such as price fixing, limitation of production, or market sharing. Such prohibition does not apply to a wide variety of other forms of coopera- 
tion among firms, including R\&D. The public policy (both in the US and Europe) and the resulting legislation allows firms' cooperation in $\mathrm{R} \& \mathrm{D}$ because such cooperation seems to stimulate innovation (cf., e.g., Katz, 1986; d’Aspremont \& Jacquemin, 1988; Kamien et al., 1992; Petrakis \& Poyago-Theotoky, 2002; Belleflamme \& Peitz, 2010; Becker, 2015). With the National Cooperative Research Act introduced in 1984, followed in 1993 by the National Cooperative Research and Production Act (Horvath, 2001), the United States markedly relaxed the country's anti-trust policy as regards R\&D cooperation. In Europe, changes in the law intended to stimulate R\&D cooperation among firms started in 1985 with the announcement of exemptions from the European anti-trust law (exemptions from Article 85 of the Treaty establishing the European Economic Community) for certain forms of agreements between enterprises with regard to $R \& D$ (Kaiser, 2002). These changes were accompanied by the emergence of numerous programmes co-financed by the European Commission that promoted cooperation among firms in R\&D. Examples of such programmes include ESPRIT (European Strategic Programme for Research in Information Technologies) which covered joint R\&D in the area of IT and electronics (Horvath, 2001).

Thus, the public innovation policy and the resulting laws allow cooperation among firms in $\mathrm{R} \& \mathrm{D}$ since it is believed to stimulate innovation. However, such conclusions may be valid for process innovation only. It does not have to be the case for product innovation and, in fact, the findings of this paper show that it is not. The present analysis shows that for markets with a relatively fierce quality competition, the industry ends up with the R\&D cartel which brings the loss of product innovation compared with R\&D competition. For markets with a mild quality competition, the industry ends up with the full industry cartel which brings both the loss of product innovation and loss of consumer surplus.

$\mathrm{R} \& \mathrm{D}$ competition and $\mathrm{R} \& \mathrm{D}$ cartelisation ( $\mathrm{R} \& \mathrm{D}$ cooperation) are sometimes regarded as two competing public policy solutions to promote enterprise innovation (cf., d'Aspremont \& Jacquemin, 1988; Kamien et al., 1992; Leibowicz, 2018). Therefore, although for process innovations, R\&D cartelisation appears to be an effective policy solution that enhances innovation, this does not have to be a case in the context of product innovations. On the contrary, this paper shows that when it comes to product innovations, R\&D cartelisation entails a measurable loss of innovation compared with R\&D competition. Hence, in the context of product innovation, the technology policy promoting R\&D cooperation among firms may prove to be unjustified or counterproductive.

\section{Conclusions}

The present paper complements the theoretical industrial economics literature on R\&D strategies, innovation and firm performance. The majority of studies on that topic (see, the literature review section) consider the relationship between the firm's R\&D strategies and process innovation. The present paper investigated the relationship between the firm's R\&D strategies and product innovation.

In this paper, the focus was placed on oligopolistic industries with differentiated products and simultaneous price and quality competition. Such a business environment is not unique in market-based economies worldwide (Storper, 1985; Flath, 2012; Mosconi, 2015; Liu \& 
Atuahene-Gima, 2018). For example, according to Flath (2012), such a business environment constitutes up to 50 per cent of industries in Japan. The real-life examples of those industries are: consumer goods (e.g., beverages, beer, cotton fabrics), fishing nets, medicines, paints, pianos, printing machines, tires and tubes for motor vehicles (Chioveanu, 2012; Flath, 2012).

The findings suggest that oligopolistic markets with differentiated products and simultaneous price and quality competition are at risk of cartel formation, either at the R\&D stage only (the $\mathrm{R} \& \mathrm{D}$ cartel), or both at the stage of $\mathrm{R} \& \mathrm{D}$ and production (the full industry cartel). Such strategies are preferred (they bring higher profits) by firms compared with the R\&D competition strategy. Based on the optimisation model, it is suggested that the considered markets with a high sensitivity of consumers to product quality enhancements and a fierce quality competition end up with the creation of an R\&D cartel, which results in a loss of product innovation compared with the $\mathrm{R} \& \mathrm{D}$ competition. In turn, the oligopolistic industries with price and quality competition, consumers who do not attach an excessive value to product quality enhancements, and quality competition which is not very intense, probably form a full industry cartel. Such a cartel will lead to a loss of product innovation and consumer surplus via higher prices lower outputs compared with the R\&D competitive scenario.

This paper carries significant implications for business managers and policy-makers. Managers of firms operating in markets with differentiated goods and simultaneous price and quality competition may now find a cooperative product R\&D strategy not very appealing, when the major objective of the firm is to innovate. Policy-makers may now be more cautious about promoting R\&D cooperation between firms, when they aim to cooperate in product R\&D. Such cooperative agreements may lead to a reduction of a product innovation and consumer surplus compared with the R\&D competition.

As regards the limitations of this paper, not all possible R\&D strategies are considered. The paper focused on the three fundamental R\&D strategies, as in d'Aspremont and Jacquemin (1988), R\&D competition, R\&D cartelisation, and full industry cartelisation, leaving RJVs aside. Certainly, in the future research, it is planned to use the product innovation model developed in this paper and consider the relationship between RJV strategies of firms and their product innovation and performance.

\section{Funding}

The research was supported by National Science Centre, Poland, grant number UMO2017/25/B/HS4/01632.

\section{References}

Acs, Z., \& Audretsch, D. (1987). Innovation, market structure, and firm size. The Review of Economics and Statistics, 69, 567-574. https://doi.org/10.2307/1935950

Aguiar, L., \& Gagnepain, P. (2017). European cooperative R\&D and firm performance: Evidence based on funding differences in key actions. International Journal of Industrial Organization, 53, 1-31. https://doi.org/10.1016/j.ijindorg.2016.12.007

Anderton, B. (1999). Innovation, product quality, variety, and trade performance: an empirical analysis of Germany and the UK. Oxford Economic Papers, 51, 152-167. https://doi.org/10.1093/oep/51.1.152 
Arslan-Ayaydin, O., Barnum, D., Karan, M. B., \& Ozdemir, A. H. (2014). How is moral hazard related to financing R\&D and innovations? European Research Studies, XVII, 111-131. https://doi.org/10.2139/ssrn.2377788

Aschhoff, B., \& Schmidt, T. (2008). Empirical evidence on the success of R\&D cooperation - happy together? Review of Industrial Organization, 33, 41-62. https://doi.org/10.1007/s11151-008-9179-7

Atallah, G. (2002). Vertical R\&D spillovers, cooperation, market structure, and innovation. Economics of Innovation and New Technology, 11, 179-209. https://doi.org/10.1080/10438590210903

Becker, B. (2015). Public R\&D policies and private R\&D investment: A survey of the empirical evidence. Journal of Economic Surveys, 29, 917-942. https://doi.org/10.1111/joes.12074

Becker, W., \& Dietz, J. (2004). R\&D cooperation and innovation activities of firms - evidence for the German manufacturing industry. Research Policy, 33, 209-223.

https://doi.org/10.1016/j.respol.2003.07.003

Belderbos, R., Carree, M., \& Lokshin, B. (2004). Cooperative R\&D and firm performance. Research Policy, 33, 1477-1492. https://doi.org/10.1016/j.respol.2004.07.003

Belderbos, R., Carree, M., \& Lokshin, B. (2006). Complementarity in R\&D cooperation strategies. Review of Industrial Organization, 28, 401-426. https://doi.org/10.1007/s11151-006-9102-z

Belderbos, R., Gilsing, V., Lokshin, B., Carree, M., \& Sastre, J. (2018). The antecedents of new R\&D collaborations with different partner types: on the dynamics of past R\&D collaboration and innovative performance. Long Range Planning, 51, 285-302. https://doi.org/10.1016/j.lrp.2017.10.002

Belleflamme, P., \& Peitz, M. (2010). Industrial organization. markets and strategies. Cambridge: Cambridge University Press. https://doi.org/10.1017/CBO9780511757808

Blattberg, R., \& Wisniewski, K. (1989). Price-induced patterns of competition. Marketing Science, 8, 291-309. https://doi.org/10.1287/mksc.8.4.291

Bourreau, M., \& Dogan, P. (2010). Cooperation in product development and process R\&D between competitors. International Journal of Industrial Organization, 28, 176-190. https://doi.org/10.1016/j.ijindorg.2009.07.010

Bourreau, M., Dogan, P., \& Manant, P. (2016). Size of RJVs with partial cooperation in product development. International Journal of Industrial Organization, 46, 77-106. https://doi.org/10.1016/j.ijindorg.2016.04.004

Brod, A., \& Shivakumar, R. (1997). Domestic versus international R\&D spillovers. Economics Letters, 56, 229-233. https://doi.org/10.1016/S0165-1765(97)81905-2

Burns, T., \& Stalker, G. (1961). The management of innovation. London: Tavistock Publications.

Bustinza, O., Gomes, E., Vendrell-Herrero, F., \& Baines, T. (2019). Product-service innovation and performance: the role of collaborative partnerships and R\&D intensity. R\&D Management, 49, 3345. https://doi.org/10.1111/radm.12269

Capuano, C., \& Grassi, I. (2019). Spillovers, product innovation and R\&D cooperation: a theoretical model. Economics of Innovation and New Technology, 28, 197-216. https://doi.org/10.1080/10438599.2018.1461333

Chioveanu, I. (2012). Price and quality competition. Journal of Economics, 107, 23-44. https://doi.org/10.1007/s00712-011-0259-z

Cohen, W., Levin, R., \& Mowery, D. (1987). Firm size and R\&D intensity: a re-examination. NBER Working Papers, No. 2205. https://doi.org/10.3386/w2205

Connor, J., \& Lande, R. (2005). How high do cartels raise prices? Implications for optimal cartel fines. Tulane Law Review, 80, 513-516.

Czarnitzki, D., Ebersberger, B., \& Fier, A. (2007). The relationship between R\&D collaboration, subsidies and R\&D performance: Empirical evidence from Finland and Germany. Journal of Applied Econometrics, 22, 1347-1366. https://doi.org/10.1002/jae.992 
d'Aspremont, C., Jacquemin, A., Gabszewicz, J., \& Weymark, J. (1983). On the stability of collusive price leadership. The Canadian Journal of Economics, 16, 17-25. https://doi.org/10.2307/134972

d'Aspremont, C., \& Jacquemin, A. (1988). Cooperative and noncooperative R\&D in duopoly with spillovers. American Economic Review, 78, 1133-1137.

De Bondt, R., \& Veugelers, R. (1991). Strategic investment with spillovers. European Journal of Political Economy, 7, 345-366. https://doi.org/10.1016/0176-2680(91)90018-X

Ding, M., Ross, W., \& Rao, V. (2010). Price as an indicator of quality: implications for utility and demand functions. Journal of Retailing, 86, 69-84. https://doi.org/10.1016/j.jretai.2010.01.002

Donsimoni, M., Economides, N., \& Polemarchakis, H. (1986). Stable cartels. International Economic Review, 27, 317-327. https://doi.org/10.2307/2526507

Dosi, G. (1988). Sources, procedures, and microeconomic effects of innovation. Journal of Economic Literature, 26, 1120-1171.

Dwicahyani, A., Rosyidi, C., \& Pujiyanto, E. (2019). Minimizing gap of utility between consumer and producer in a duopoly market considering outsourcing decision, price, and product tolerance. Production \& Manufacturing Research, 7, 23-43. https://doi.org/10.1080/21693277.2019.1571957

Flath, D. (2012). Are there any cournot industries in Japan? The Japanese Economy, 39, 3-36. https://doi.org/10.2753/JES1097-203X390201

Geroski, P. (1995). Do spillovers undermine the incentive to innovate? In S. Dowrick (Ed.), Economic approaches to innovation. Aldershot: Edward Elgar.

Goldberg, P. (1995). Product differentiation and oligopoly in international markets: the case of the U.S. automobile industry. Econometrica, 63, 891-951. https://doi.org/10.2307/2171803

Gostkowski, M. (2018). Elasticity of consumer demand: estimation using a quadratic almost ideal demand system. Econometrics, 22, 68-78. https://doi.org/10.15611/eada.2018.1.05

Griliches, Z. (1998). R\&D and productivity: the econometric evidence. Chicago: University of Chicago Press. https://doi.org/10.7208/chicago/9780226308906.001.0001

Hinloopen, J. (2000). Strategic R\&D cooperatives. Research in Economics, 54, 153-185. https://doi. org/10.1006/reec.1999.0211

Hofman, E., Faems, D., \& Schleimer, S. (2017). Governing collaborative new product development: toward a configurational perspective on the role of contracts. Journal of Product Innovation Management, 34, 739-756. https://doi.org/10.1111/jpim.12412

Horvath, R. (2001). Cooperation in research and development. Barcelona: Universitat Autonoma de Barcelona.

Hult, G., Hurley, R., \& Knight, G. (2004). Innovativeness: its antecedents and impact on business performance. Industrial Marketing Management, 33, 429-438. https://doi.org/10.1016/j.indmarman.2003.08.015

Hurley, R., \& Hult, G. (1998). Innovation, market orientation, and organizational learning: an integration and empirical examination. Journal of Marketing, 62, 42-54. https://doi.org/10.1177/002224299806200303

Inkmann, J. (2000). Horizontal and vertical $R \& D$ cooperation. Centre of finance and econometrics at the university of Konstanz, discussion paper 02/2000.

Kaiser, U., \& Licht, G. (1998). R\&D cooperation and $R \& D$ intensity: theory and micro econometric evidence for German manufacturing industries. ZEW discussion paper 98-26.

Kaiser, U. (2002). An empirical test of models explaining research expenditures and research cooperation: evidence for the German service sector. International Journal of Industrial Organization, 20, 747-774. https://doi.org/10.1016/S0167-7187(01)00074-1

Kamien, M., Muller, E., \& Zang, I. (1992). Research joint ventures and R\&D cartels. American Economic Review, 82, 1293-1306. 
Kamien, M., \& Zang, I. (2000). Meet me halfway: research joint ventures and absorptive capacity. International Journal of Industrial Organization, 18, 995-1012. https://doi.org/10.1016/S0167-7187(00)00054-0

Karbowski, A. (2016). The elasticity-based approach to enterprise innovation. International Journal of Management and Economics, 49, 58-78. https://doi.org/10.1515/ijme-2016-0004

Karbowski, A., \& Prokop, J. (2018). R\&D activities of enterprises, product market leadership, and collusion. Proceedings of Rijeka Faculty of Economics: Journal of Economics and Business, 36, 735-753.

Katz, M. (1986). An analysis of cooperative research and development. RAND Journal of Economics, 17, 527-543. https://doi.org/10.2307/2555479

Kim, K. (2018). Diminishing returns to R\&D investment on innovation in manufacturing SMEs: Do the technological intensity of industry matter? International Journal of Innovation Management, 22, 1850056. https://doi.org/10.1142/S1363919618500561

Kleinknecht, A., van Montfort, K., \& Brouwer, E. (2002). The non-trivial choice between innovation indicators. Economics of Innovation and New Technology, 11, 109-121. https://doi.org/10.1080/10438590210899

Klomp, L., \& van Leeuwen, G. (2001). Linking innovation and firm performance: a new approach. International Journal of the Economics of Business, 8, 343-364. https://doi.org/10.1080/13571510110079612

Lafay, T., \& Maximin, C. (2017). How R\&D competition affects investment choices. Managerial and Decision Economics, 38, 109-124. https://doi.org/10.1002/mde.2745

Lee, C.-Y. (1999). A Theory of the Determinants of $R \& D$. Cambridge, MA: Harvard University.

Lee, C.-Y., \& Sung, T. (2005). Schumpeter's legacy: A new perspective on the relationship between firm size and R\&D. Research Policy, 34, 914-931. https://doi.org/10.1016/j.respol.2005.04.006

Lee, R., \& Murphy, J. (2008). The moderating influence of enjoyment on customer loyalty. Australasian Marketing Journal, 16, 11-21. https://doi.org/10.1016/S1441-3582(08)70011-9

Leibowicz, B. (2018). Welfare improvement windows for innovation policy. Research Policy, 47, 390-398. https://doi.org/10.1016/j.respol.2017.12.009

Li, W., \& Chen, J. (2018). Pricing and quality competition in a brand differentiated supply chain. International Journal of Production Economics, 202, 97-108. https://doi.org/10.1016/j.ijpe.2018.04.026

Lin, B-W., Lee, Y., \& Hung, S-C. (2006). R\&D intensity and commercialization orientation effects on financial performance. Journal of Business Research, 59, 679-685. https://doi.org/10.1016/j.jbusres.2006.01.002

Liu, W., \& Atuahene-Gima, K. (2018). Enhancing product innovation performance in a dysfunctional competitive environment: The roles of competitive strategies and market-based assets. Industrial Marketing Management, 73, 7-20. https://doi.org/10.1016/j.indmarman.2018.01.006

Liu, J., Lu, K., \& Cheng, S. (2018). International R\&D Spillovers and Innovation Efficiency. Sustainability, 10, 3974. https://doi.org/10.3390/su10113974

Lööf, H., \& Heshmati, A. (2002). Knowledge capital and performance heterogeneity: a firm-level innovation study. International Journal of Production Economics, 76, 61-85. https://doi.org/10.1016/S0925-5273(01)00147-5

Martin, S. (2006). Competition policy, collusion, and tacit collusion. International Journal of Industrial Organization, 24, 159-176. https://doi.org/10.1016/j.ijindorg.2006.04.007

Mazzeo, M. (2002). Product choice and oligopoly market structure. RAND Journal of Economics, 33, 221-242. https://doi.org/10.2307/3087431

Medda, G. (2018). External R\&D, product and process innovation in European manufacturing companies. The Journal of Technology Transfer, 1-31. https://doi.org/10.1007/s10961-018-9682-4

Milbergs, E., \& Vonortas, N. (2006). Innovation metrics: measurement to insight. White paper for National Innovation Initiative. 
Miyagiwa, K. (2009). Collusion and research joint ventures. The Journal of Industrial Economics, 57, 768-784. https://doi.org/10.1111/j.1467-6451.2009.00399.x

Mosconi, F. (2015). The new European industrial policy. London: Routledge. https://doi.org/10.4324/9781315761756

Motta, M. (1992). Cooperative R\&D and vertical product differentiation. International Journal of Industrial Organization, 10, 643-661. https://doi.org/10.1016/0167-7187(92)90064-6

Park, S. (2011). $R \& D$ intensity and firm size revisited. Los Angeles: University of California, Los Angeles.

Petrakis, E., \& Poyago-Theotoky, J. (2002). R\&D Subsidies versus R\&D cooperation in a duopoly with spillovers and pollution. Australian Economic Papers, 41, 37-52. https://doi.org/10.1111/1467-8454.00148

Prokop, J. (1999). Process of dominant-cartel formation. International Journal of Industrial Organization, 17, 241-257. https://doi.org/10.1016/S0167-7187(97)00040-4

Qiu, L. (1997). On the dynamic efficiency of Bertrand and Cournot equilibria. Journal of Economic Theory, 75, 213-229. https://doi.org/10.1006/jeth.1997.2270

Ruff, L. (1969). Research and technological progress in a Cournot economy. Journal of Economic Theory, 1, 397-415. https://doi.org/10.1016/0022-0531(69)90025-8

Scherer, F. (1980). Industrial market structure and economic performance. Chicago: Rand McNally College Publishing Company.

Scherer, F. (1984). Using linked patent and R\&D data to measure technology flows. In Z. Griliches (Ed.), $R \& D$ patents, and productivity. Chicago: University of Chicago Press.

Spence, M. (1984). Cost reduction, competition, and industry performance. Econometrica, 52, 101-121. https://doi.org/10.2307/1911463

Storper, M. (1985). Oligopoly and the product cycle: essentialism in economic geography. Economic Geography, 61, 260-282. https://doi.org/10.2307/143561

Turulja, L., \& Bajgoric, N. (2019). Innovation, firms' performance and environmental turbulence: is there a moderator or mediator? European Journal of Innovation Management, 22, 213-232. https://doi.org/10.1108/EJIM-03-2018-0064

Tushman, M., \& Smith, W. (2002). Organizational technology. In J. Baum (Ed.), Companion to organization. Malden, MA: Blackwell.

Van Beers, C., \& Zand, F. (2014). R\&D cooperation, partner diversity, and innovation performance: an empirical analysis. Journal of Product Innovation Management, 31, 292-312. https://doi.org/10.1111/jpim.12096

Vonortas, N. (2018). International perspectives on innovation: introduction. The Journal of Technology Transfer, 43, 259-262. https://doi.org/10.1007/s10961-017-9569-9

Wan, M., Huang, Y., Zhao, L., Deng, T., \& Fransoo, J. (2018). Demand estimation under multi-store multi-product substitution in high density traditional retail. European Journal of Operational Research, 266, 99-111. https://doi.org/10.1016/j.ejor.2017.09.014

Whelan, P. (2013). Cartel criminalization and the challenge of "moral wrongfulness". Oxford Journal of Legal Studies, 33, 535-561. https://doi.org/10.1093/ojls/gqt010

Zhou, X., Shan, M., \& Li, J. (2018). R\&D strategy and innovation performance: the role of standardization. Technology Analysis \& Strategic Management, 30, 778-792. https://doi.org/10.1080/09537325.2017.1378319

Ziss, S. (1994). Strategic R\&D with spillovers, collusion and welfare. The Journal of Industrial Economics, 17, 375-393. https://doi.org/10.2307/2950444 